\title{
Pengaruh Kualitas Pelayanan terhadap Loyalitas Pelanggan dengan Kepuasan Pelanggan Sebagai Variabel Medisi di Prime Plaza Suites, Bali
}

\author{
I Ketut Surata1, I Gusti Agung Febrianto*2, Anak Agung Istri Manik Mahayani³ \\ 1,2,3Program Studi Bisnis Hospitality, Politeknik Pariwisata Bali \\ Jalan Dharmawangsa, Kampial, Nusa Dua, Bali, Indonesia. \\ 1surata_iketut@yahoo.com, *2igustiagung.febrianto@gmail.com,33unganik17@gmail.com \\ *Coresponding author
}

Received: November, 2020 $\quad$ Accepted: November, 2020 $\quad$ Published: Desember, 2020

\begin{abstract}
The aims of this study were to (1) analyze the influence of service quality to customer loyalty, (2) analyze the influence of service quality to customer satisfaction, (3) analyze the influence of customer satisfaction to customer loyalty, and (4) analyze the influence of service quality to customer loyalty with customer satisfaction as mediating variabel in Prime Plaza Suites Sanur - Bali. This study used questionnaires as the data collection techniques which were distributed to 100 guests who have stayed at Prime Plaza Suites Sanur - Bali as the respondents of this study. Data were analyzed quantitatively using classic assumption testing, simple linear regression analysis, $t$-test, path analysis and analysis of determination. The result of this study indicated (1) service quality has a positive and significant effect on customer loyalty $(\beta=0,257 ; t$-value $=2,638 ; p<0,05)$, (2) service quality has a positive and significant effect on customer satisfaction $(\beta=0,964 ; t$-value $=30,814 ; p<0,05)$, (3) customer satisfaction has a positive and significant effect on customer loyalty $(\beta=0,252 ; t$ value $=2,617 ; p<0,05$ ) and (4) customer satisfaction has a partial mediating on the positive and significant relationship between service quality on customer loyalty $\beta=0,961 ; t$-value $=$ 29,552; $p<0,05)$.
\end{abstract}

Keywords: Service Quality, Customer Loyalty, Customer Satisfaction

\begin{abstract}
Abstrak
Penelitian ini bertujuan untuk (1) menganalisis pengaruh kualitas pelayanan terhadap loyalitas pelanggan, (2) menganalisis pengaruh kualitas pelayanan terhadap kepuasan pelanggan, (3) menganalisis pengaruh kepuasan pelanggan terhadap loyalitas pelanggan dan (4) menganalisis pengaruh kualitas pelayanan terhadap loyalitas pelanggan dengan kepuasan pelanggan sebagai variabel mediasi. Teknik pengumpulan data yang digunakan adalah dengan menyebar kuesioner kepada responden yang merupakan tamu menginap di Prime Plaza Suites Sanur - Bali sejumlah 100 orang. Data dianalisis secara kuantitatif menggunakan uji asumsi klasik, uji analisis regresi linear sederhana, uji analisis jalur dan analisis determinasi. Hasil penelitian ini menunjukkan (1) kualitas pelayanan memiliki pengaruh yang positif dan signifikan terhadap loyalitas pelanggan $(\beta=0,257$; $t$-hitung= 2,638; $p<0,05$ ), (2) kualitas pelayanan memiliki pengaruh yang positif dan signifikan
\end{abstract}


terhadap kepuasan pelanggan $(\beta=0,964 ;$ t-hitung $=30,814 ; p<0,05)$, (3) kepuasan pelanggan memiliki pengaruh yang positif dan signifikan terhadap loyalitas pelanggan ( $\beta=$ 0,252 ; -hitung $=2,617 ; p<0,05$ ) dan (4) kepuasan pelanggan memiliki peran mediasi secara parsial pada pengaruh positif dan signifikan dari kualitas pelayanan terhadap loyalitas pelanggan $(\beta=0,961 ; t$-hitung $=29,552 ; p<0,05)$.

Kata kunci: Kualitas Pelayanan, Loyalitas Pelanggan, Kepuasan Pelanggan

\section{PENDAHULUAN}

Pariwisata merupakan salah satu industri terbesar dan tercepat perkembangannya didunia. Hal tersebut dapat dilihat pada naiknya jumlah kunjungan wisatawan mancanegara ke Bali dari tahun 2016 hingga 2019. Pertumbuhan pariwisata ini memberikan dampak pada persaingan yang semakin meningkat dalam industri perhotelan. Untuk mendapatkan keunggulan kompetitif pengembangan kualitas pelayanan merupakan hal yang sangat penting bagi perusahaan selain menjadi kode akses penting dari industri perhotelan, kualitas pelayanan juga menjadi bottom line bagi perusahaan (Mohamad dkk., 2017).

Prime Plaza Suites Sanur - Bali adalah salah satu hotel bintang empat di Bali yang dapat dikatakan sukses dalam pertumbuhan industri perhotelan dan lingkungan kompetitif dengan bergantung pada kualitas pelayanan. Hal tersebut dapat dilihat dari adanya peningkatan nilai kualitas pelayanan yang diperoleh melalui hasil rekapitulasi guest comment dari tamu yang menginap. Menurut Ananda dan Devesh (2016:335) "kualitas pelayanan merupakan pengalaman psikologis pelanggan yang dibandingkan dengan harapan mereka, sehingga kesenjangan antara harapan dan yang dirasakan dapat diukur untuk mengetahui efektifitas pelayanan yang disampaikan. Sejauh ini SERVQUAL atau ada yang menyebutkan RATER merupakan model yang paling populer dan paling teruji. Pada tahun 2016 nilai kualitas pelayanan sebesar 9.08. Pada tahun 2017 nilai kualitas pelayanan sebesar 9,06. Pada 2018 nilai kualitas pelayanan sebesar 9.17. Pada tahun 2019 nilai kualitas pelayanan sebesar 9.34.

Hubungan antara kualitas pelayanan dan loyalitas pelanggan telah terbukti menjadi kasus di banyak literatur (Sudigdo dkk., 2019). Berbagai artikel telah mendukung hubungan kuat antara kualitas pelayanan dan loyalitas pelanggan serta mengevaluasi dua variabel ini memiliki hubungan langsung dan tidak langsung (Kandampully dkk., 2011a). Menurut (Khalifa, 2015; Sudigdo dkk., 2019) ketika kualitas pelayanan mampu memuaskan, pelanggan bersedia untuk merekomendasikan merek dan membeli lebih banyak. Hal ini menunjukkan untuk mencapi loyalitas pelanggan tidak hanya melalui kualitas pelayanan namun adanya perasaan puas terhadap layanan yang diberikan terlebih dahulu.

Menurut Priansah (2017:196) kepuasan pelanggan adalah perasaan senang atau kecewa seseorang yang muncul setelah membandingkan antara kinerja (hasil) produk yang diperkirakan terhadap kinerja (atau hasil) yang diharapkan. Pada tahun 2016 nilai kepuasan pelanggan di Prime Plaza Suites Sanur - Bali sebesar 8,91. Pada tahun 2017 nilai kepuasan pelanggan sebesar 8,74. Pada tahun 2018 nilai kepuasan pelanggan adalah sebesar 8,91. Pada tahun 2019 nilai kepuasan pelanggan mengalami peningkatan dengan total nilai sebesar 8,98. Hal tersebut mengindikasika bahwa Prime Plaza Suites Sanur Bali mampu memberikan pelayanan yang memuaskan sehingga diharapkan dapat membentuk loyalitas pelanggan.

Menurut (Abd-Elaziz dkk., 2015; Trung dan Khalifa, 2019) loyalitas pelanggan adalah langkah berikutnya dari kepuasan dan pelanggan yang puas lebih cenderung menggambarkan loyalitas melalui pembelian berulang yang dapat mendukung dalam meningkatkan pendapatan hotel dan kecenderungan untuk memberikan kata-kata positit dari mulut ke mulut. Pada tahun 2016 kontribusi tamu menginap berdasarkan 
rekomendasi adalah 2.901. Pada tahun 2017 jumlah tamu menginap berdasarkan rekomendasi adalah 3.157. Pada tahun 2018 jumlah tamu menginap berdasarkan rekomendasi mengalami penurunan dengan kontribusi tamu menginap berdasarkan rekomendasi adalah 3.107. Pada tahun 2019 kontribusi tamu menginap berdasarkan rekomendasi mengalami peningkatan dengan jumlah tamu menginap berdasarkan rekomendasi adalah 3.352, selain dari itu tamu yang loyal juga dapat dilihat melalui pembelian berulang yang dilakukan oleh pelanggan hotel.

Menurut Rousan sebagaimana yang dikutip oleh Badarudin (2010) mengungkapkan bahwasannya loyalitas pelanggan terjadi ketika ada pengulangan pembeliaan kepada pelanggan yang sama dan kesediaan mereka untuk merekomendasikan produk terhadap pelanggan lain tanpa manfaat langsung dan akhirnya penggunaan berulang akan menghasilkan sikap yang positif. Pada tahun 2016 kontribusi kamar terjual yang berasal dari tamu repeater adalah 1.879. Pada tahun 2017 jumlah tamu repeater mengalami peningkatan dengan kontribusi tamu repeater adalah 2.365. Pada tahun 2018 jumlah tamu repeater mengalami penurunan dengan kontribusi tamu repeater adalah 2.053. Pada tahun 2019 jumlah tamu repeater mengalami peningkatan dengan kontribusi tamu repeater adalah 2.351. Berdasarkan paparan diatas dapat diindikasikan bahwa, terjadinya ketidaksesuaian terhadap peningkatan pelayanan yang memuasakan pada tahun 2018 yang diharapkan dapat meningkatkan pula tamu agar tetap loyal dengan adanya pembelian berulang namun yang terjadi jumlah tamu menginap berdasarkan rekomendasi dan jumlah tamu repeater mengalami ketidakstabilan dan tidak seiiring dengan peningkatan pada pelayanan yang memuaskan.

Penelitian ini mengambil lokasi di Prime Plaza Suites Sanur - Bali. Berdasarkan paparan data tersebut maka dapat dilihat bahwa peningkatan nilai kualitas pelayanan dari Tahun 2018 sampai Tahun 2019 yang diiringi dengan kepuasan pelanggan namun, tidak disertai dengan peningkatan jumlah tamu repeater dan jumlah tamu menginap berdasarkan rekomendasi di Prime Plaza Suites Sanur - Bali. Berdasarkan latar belakang tersebut, maka perlu dilakukan penelitian tentang Pengaruh Kualitas Pelayanan terhadap Loyalitas Pelanggan dengan Kepuasan Pelanggan sebagai variabel mediasi di Prime Plaza Suites Sanur - Bali.

Menurut Ananda dan Devesh (2016:335) "Service quality is psychological 'experience' of the customers in comparison with their 'expectation'". Dapat dijelaskan bahwa kualitas pelayanan merupakan pengalaman psikologis pelanggan yang dibandingkan dengan harapan mereka. Menurut Parasuraman dkk yang dikutip oleh Sudarso (2012: 57), kualitas pelayanan merupakan penilaian atau sikap global berkenaan dengan superioritas suatu layanan. Definisi ini didasarkan pada 3 landasan konseptual utama, yaitu (1) kualiats pelayanan lebih sulit dievaluasi pelanggan dibandingkan dengan kualitas barang, (2) persepsi terhadap kualitas pelayanan merupakan hasil perbandingan antara harapan pelanggan dengan kinerja aktual layanan, (3) evaluasi kualitas pelayanan tidak hanya dilakukan atas hasil layanan, namun juga mencakup evaluasi terhadap proses penyampaian layanan. Menurut Kotler dan Keller (2012:396) terdapat 5 dimensi kualitas pelayanan yaitu: bukti fisik, kehandalan, daya tanggap, jaminan dan empati.

Gramer dan Brown sebagaimana yang dikutip oleh Galib Mohammed (2013), memberikan definisi mengenai loyalitas yaitu derajat sejauh mana seorang pelanggan menunjukkan perilaku pembelian berulang dari suatu penyedia jasa. Selain pembelian berulang ditunjukkan adanya kecenderungan sikap positif terhadap penyedia jasa dan hanya mempertimbangkan untuk menggunakan penyedia jasa ini pada saat muncul kebutuhan untuk memakai jasa ini. Menurut Julander dkk yang dikutip oleh Kandampully, J., \& Suhartanto, D. (2000) terdapat dua dimensi loyalitas pelanggan yaitu: perilaku loyalitas, hal ini mengacu pada perilaku pelanggan pada pembeliaan berulang, menunjukkan preferensi terhadap merek atau layanan dari waktu ke waktu dan sikap 
loyalitas, hal ini mengacu pada niat pelanggan untuk membeli kembali dan merekomendasikan kepada orag lain.

Menurut Priansah (2017:196) mendefinisikan bahwa kepuasan pelanggan adalah perasaan senang atau kecewa seseorang yang muncul setelah membandingkan antara kinerja (hasil) produk yang diperkirakan terhadap kinerja (atau hasil) yang diharapkan. Menurut Kotler dalam Etta Mamang dan Sopiah (2013:181) mendefinisikan bahwa pelanggan yang merasa puas pada produk atau jasa yang dibeli dan digunakannya akan kembali menggunakan jasa atau produk yang ditawarkan, hal tersebut akan membangun kesetiaan pelanggan. Menurut Skogland dan Siguaw (2004) mengemukakan ada empat dimensi yang mempengaruhi kepuasan pelanggan antara lain: kualitas pelayanan, kualitas produk, harga, dan lokasi.

Tujuan dari penelitian ini adalah sebagai berikut: (1) Untuk menganalisis pengaruh kualitas pelayanan terhadap loyalitas pelanggan di Prime Plaza Suites Sanur Bali (2) Untuk menganalisi pengaruh kualitas pelayanan terhadap kepuasan pelanggan di Prime Plaza Suites Sanur - Bali (3) Untuk menganalisi pengaruh kepuasan pelanggan terhadap loyalitas pelanggan di Prime Plaza Suites Sanur - Bali (4) Untuk menganalisis pengaruh kualitas pelayanan terhadap loyalitas pelanggan dengan kepuasan pelanggan sebagai variabel mediasi di Prime Plaza Suites Sanur - Bali.

\section{METODE PENELITIAN}

\subsection{Model Penelitian}

Penelitian ini memiliki satu variabel independen dan satu variabel mediasi yang akan diukur pengaruhnya terhadap variabel dependen. Satu variabel independen tersebut adalah kualitas pelayanan dan satu variabel mediasi tersebut adalah kepuasan pelanggan. Sedangkan variabel dependen dalam penelitian ini yaitu loyalitas pelanggan. Penelitian ini bertujuan untuk menganalisis pengaruh kualitas pelayanan terhadap loyalitas pelanggan dnegan kepuasan pelanggan sebagai variabel mediasi di Prime Plaza Suites Sanur - Bali.

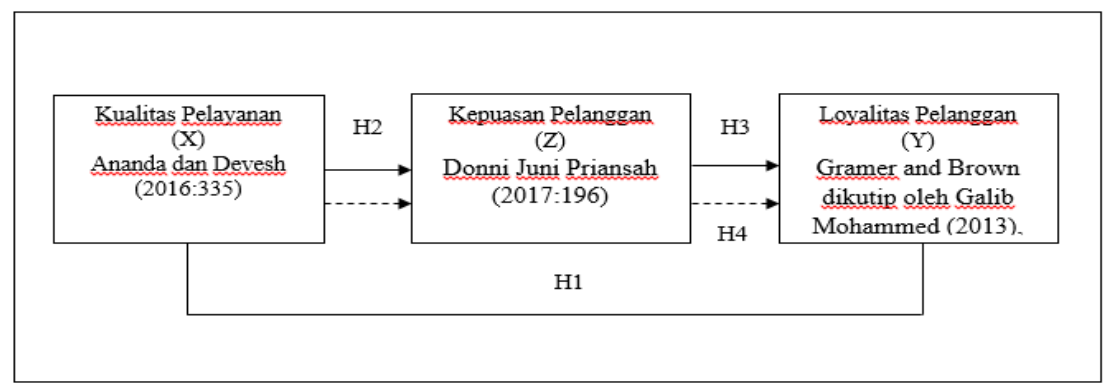

Gambar 1: Kerangka Pemikiran

Berdasarkan kerangka pemikiran pada Gambar 1, dapat ditarik hipotesis yang berkaitan dengan variabel-variabel penelitian, yaitu sebagai berikut:

Ho1: Tidak adanya pengaruh antara Kualitas Pelayanan terhadap Loyalitas Pelanggan di Prime Plaza Suites Sanur - Bali.

Ha1: Terdapat pengaruh antara Kualitas Pelayanan terhadap Loyalitas Pelanggan di Prime Plaza Suites Sanur - Bali.

Ho2: Tidak adanya pengaruh antara Kualitas Pelayanan terhadap Kepuasan Pelanggan di Prime Plaza Suites Sanur - Bali.

Ha2: Terdapat pengaruh antara Kualitas Pelayanan terhadap Kepuasan Pelanggan di Prime Plaza Suites Sanur - Bali.

Ho3: Tidak adanya pengaruh antara Kepuasan Pelanggan terhadap Loyalitas Pelanggan di Prime Plaza Suites Sanur - Bali. 
Ha3: Terdapat pengaruh antara Kepuasan Pelanggan terhadap Loyalitas Pelanggan di Prime Plaza Suites Sanur - Bali.

Ho4: Tidak adanya pengaruh antara Kualitas Pelayanan terhadap Loyalitas Pelanggan dengan Kepuasan Pelanggan sebagai variabel mediasi di Prime Plaza Suites Sanur - Bali.

Ha4: Terdapat pengaruh antara Kualitas Pelayanan terhadap Loyalitas Pelanggan dengan Kepuasan Pelanggan sebagai variabel mediasi di Prime Plaza Suites Sanur - Bali.

\subsection{Metode Pengumpulan Data}

Data dalam penelitian ini dikumpulkan dengan cara melakukan penyebaran kuesioner online melalui google form kepada 100 tamu yang pernah menginap di Prime Plaza Suites Sanur - Bali. Uji instrumen penelitian yang digunakan adalah uji validitas dan uji reliabilitas. Uji kelayakan data yang digunakan adalah uji asumsi klasik (uji normalitas, multikolinearitas, dan uji heterokedastisitas). Teknik analisis dada yang digunakan dalam penelitian ini adalah analisis regresi linier sederhana, uji $t$, analisis jalur dan koefisien determinasi dengan menggunakan program statistika SPSS for Windows version 25.0.

\subsection{Pengukuran}

Instrumen penelitian yang digunakan dalam penelitian ini adalah kuesioner. Kuesioner yang disebar merupakan instrumen penelitian yang mengukur ketiga variabel penelitian yaitu, kualitas pelayanan, loyalitas pelanggan dan kepuasan pelanggan. Instrumen penelitian tersebut diukur dengan menggunakan skala likert 5 poin yang indikatornya di adaptasi dari penelitian terdahulu. Variabel kualitas pelayanan mengukur lima dimensi dengan menggunakan 10 indikator pernyataan dari penelitian oleh Mohamud dkk., (2017) Variabel loyalitas pelanggan mengukur 2 dimensi dengan menggunakan 7 indikator pernyataan yang dikembangkan dari penelitian oleh Mohamad dkk., (2017). Variabel kepuasan pelanggan mengukur 4 dimensi dengan menggunakan 7 indikator pernyataan dari penelitian oleh Skogland dan Siguaw (2004).

\section{HASIL DAN PEMBAHASAN}

\subsection{Hasil Penelitian}

Respon rate menunjukkan $100 \%$ atau sejumlah 100 kuesioner kembali dan layak untuk dianalisis. Karakteristik responden dapat dikelompokkan berdasarkan jenis kelamin, usia, tingkat pendidikan, status pekerjaan, frekuensi berkunjung dan lama menginap. Karakteristik responden berdasarkan jenis kelamin yaitu responden laki-laki lebih banyak dengan total 64 orang atau sebesar $64 \%$ sedangkan perempuan sebanyak 36 orang atau sebesar 36\%. Karakteristik responden berdasarkan usia sejumlah 45 orang (45\%) berumur 21-30 tahun dan sejumlah 17 orang (17\%) berumur 31-40 tahun serta sejumlah 38 orang (38\%) berumur diatas 40 tahun. \%. Karakteristik responden berdasarkan tingkat pendidikan yaitu sejumlah 7 orang (7\%) yang berlatar belakang pendidikan SMA/ SMK, 30 orang (30\%) berlatar belakang pendidikan Diploma. Sebanyak 53 responden (53\%) berlatar belakang pendidikan Sarjana dan 10 responden $(10 \%)$ berlatar belakang pendidikan Pascasarjana. Karakteristik responden berdasarkan status pekerjaan yaitu sebanyak 20 responden (20\%) merupakan pegawai negeri sipil, sementara sebanyak 42 responden (42\%) merupakan pegawai swasta, sebanyak 31 responden (31\%) adalah pebisnis dan 26 responden (26\%) memiliki pekerjaan lainnya. Karakteristik responden berdasarkan frekuensi berkunjung yaitu jawaban 1-2 kali sebanyak 61 responden (61\%), dengan jawaban 3-5 kali sebanyak 27 responden ( 27\%) dan dengan jawaban $>5$ kali sebanyak 12 responden (12\%). Karakteristik responden berdasarkan lama menginap jawaban 1-3 malam sebanyak 68 responden (68\%), dengan 
jawaban 4-6 malam sebanyak 29 responden (29\%) dan dengan jawaban $\geq 7$ malam sebanyak 3 responden (3\%).

Pengujian instrumen penelitian dilakukan denagn uji validitas dan uji reliabilitas. Hasil dari uji validitas menyatakan keseluruhan item pernyataan mengenai kualitas pelayanan, kepuasan pelanggan dan loyalitas pelanggan valid karena nilai rhitung $>$ rtabel (rtabel $=0,196$ ). Hasil uji reliabilitas menyatakan bahwa item pernyataan dari variabel kualitas pelayanan, kepuasan pelanggan dan loyalitas pelanggan lebih besar dari 0,60 sehingga, dapat disimpulkan bahwa butir atau item pertanyaan kuesioner yang digunakan sudah dinyatakan reliabel untuk digunakan di dalam pengambilan data penelitian.

\subsection{Pembahasan}

Teknik analisis data yang digunakan untuk menguji hipotesis satu sampai tiga adalah analisis regresi linear sederhana, sedengkan hipotesis empat diuji dengan menggunakan analisis jalur:

1) Pengaruh kualitas pelayanan terhadap loyalitas pelanggan di Prime Plaza Suites Sanur - Bali.

Hasil pengujian hipotesis yang pertama diperoleh hasil penolakan H0, yang menyatakan bahwa kualitas pelayanan terhadap loyalitas pelanggan berpengaruh positif dan secara statistik signifikan $(\beta=0,257$; thitung $=2,638$; $p<0,05)$. Hasil ini mengindikasikan bahwa jika kualitas pelayanan mengalami kenaikan satu satuan, maka loyalitas pelanggan akan mengalami kenaikan sebesar 0,257. Nilai R2 adalah sebesar 0,066 yang memiliki arti bahwa dimensi kualitas pelayanan mampu menjelaskan variansi variabel loyalitas pelanggan sebesar 6,6\% dan sisanya sebesar 93,4\% dipengaruhi oleh variabel lain yang tidak dimasukkan dalam model penelitian ini.

2) Pengaruh kualitas pelayanan terhadap kepuasan pelanggan di Prime Plaza Suites Sanur - Bali.

Hasil pengujian hipotesis yang kedua diperoleh hasil penolakan H0, yang menyatakan bahwa kualitas pelayanan terhadap kepuasan pelanggan berpengaruh positif dan secara statistik signifikan $(\beta=0,964$; thitung $=30,814 ; \mathrm{p}<0,05)$. Hasil ini mengindikasikan bahwa jika kualitas pelayanan mengalami kenaikan satu satuan, maka kepuasan pelanggan akan mengalami kenaikan sebesar 0,964. Nilai R2 adalah sebesar 0,906 yang memiliki arti bahwa dimensi kualitas pelayanan mampu menjelaskan variansi variabel kepuasan pelanggan sebesar 90,6\% dan sisanya sebesar 9,4\% dipengaruhi oleh variabel lain yang tidak dimasukkan dalam model penelitian ini.

3) Pengaruh kepuasan pelanggan terhadap loyalitas pelanggan di Prime Plaza Suites Sanur - Bali.

Hasil pengujian hipotesis yang ketiga diperoleh hasil penolakan H0, yang menyatakan bahwa kepuasan pelanggan terhadap loyalitas pelanggan berpengaruh positif dan secara statistik signifikan $(\beta=0,252$; thitung $=2,617$; $\mathrm{p}<$ $0,05)$. Hasil ini mengindikasikan bahwa jika kepuasan pelanggan mengalami kenaikan satu satuan, maka loyalitas pelanggan akan mengalami kenaikan sebesar 0,252 . Nilai R2 adalah sebesar 0,566 yang memiliki arti bahwa dimensi kepuasan pelanggan mampu menjelaskan variansi variabel loyalitas pelanggan sebesar $56,6 \%$ dan sisanya sebesar 33,4\% dipengaruhi oleh variabel lain yang tidak dimasukkan dalam model penelitian ini.

4) Pengaruh kualitas pelayanan terhadap loyalitas pelanggan dengan kepuasan pelanggan sebagai variabel mediasi di Prime Plaza Suites Sanur - Bali.

Pada saat pengujian mediasi, dilakukan empat langkah untuk pengujian mediasi sesuai dengan konsep yang dikembangkan oleh Baron dan Kenny (1986). Analisis yang digunakan adalah analisis jalur. Langkah yang pertama adalah dengan 
meregresikan variabel independen (kualitas pelayanan) dengan variabel independen (loyalitas pelanggan). Hasil pengujian menunjukkan bahwa kualitas pelayanan berpengaruh positif dan secara statistik signifikan terhadap loyalitas pelanggan $(\beta=0,257$; thitung $=2,638 ; \mathrm{p}<0,05)$. Sehingga syarat pengujian mediasi yang pertama terpenuhi.

Langkah yang kedua adalah dengan meregresikan variabel independen (kualitas pelayanan) dengan variabel mediasi (kepuasan pelanggan). Hasil pengujian menunjukkan bahwa kualitas pelayanan berpengaruh positif dan secara statistik signifikan terhadap kepuasan pelanggan $(\beta=0,964$; thitung $=30,814 ; p<0,05)$. Sehingga syarat pengujian mediasi yang kedua terpenuhi.

Langkah yang ketiga adalah dengan meregresikan varibel medisi (kepuasan pelanggan) dengan variabel dependen (loyalitas pelanggan). Hasil pengujian menunjukkan bahwa kepuasan pelanggan berpengaruh positif dan secara statistik signifikan terhadap loyalitas pelanggan $(\beta=0,252$; thitung $=2,617 ; p<0,05)$. Sehingga syarat pengujian mediasi yang ketiga terpenuhi.

Langkah yang keempat adalah dengan meregresikan variabel independen (kualitas pelayanan) dengan variabel dependen (loyalitas pelanggan) dan menggunakan variabel mediasi (kepuasan pelanggan) sebagai variabel pengontrol. Hasil analisis menunjukkan bahwa hubungan pengaruh kualitas pelayanan terhadap loyalitas pelanggan tetap memiliki pengaruh positif dan secara statistik signifikan setelah variabel kepuasan pelanggan dikontrol $(\beta=0,961$; thitung $=29,552 ; p<0,05)$. Dengan demikian hipotesis keempat didukung, yang mengindikasikan bahwa terdapat pengaruh yang positif dan signifikan antara kualitas pelayanan terhadap loyalitas pelanggan dengan kepuasan pelanggan sebagai variabel mediasi. . Nilai R2 adalah sebesar 0,907 yang memiliki arti bahwa dimensi kepuasan pelanggan mampu memediasi antara kualitas pelayanan dan loyalitas pelanggan sebesar 90,7\% dan sisanya sebesar 9,3\% dipengaruhi oleh variabel lain yang tidak dimasukkan dalam model penelitian ini.

\section{KESIMPULAN}

Berdasarkan hasil analisis dan pembahasan diatas mengenai pengaruh kualitas pelayanan terhadap loyalitas pelanggan dengan kepuasan pelanggan sebagai variabel mediasi di Prime Plaza Suites Saur - Bali, maka dapat disimpulkan sebagai berikut: (1) kualitas pelayanan berpengaruh positif dan signifikan terhadap loyalitas pelanggan, yang didasarkan pada hasil perhitungan nilai signifikansi sebesar $0,010<0,05$, yang memiliki makna bahwa kualitas pelayanan secara statistik berpengaruh terhadap loyalitas pelanggan, (2) kualitas pelayanan berpengaruh positif dan signifikan terhadap kepuasan pelanggan, yang didasarkan pada hasil perhitungan nilai signifikansi sebesar $0,000<0,05$, yang memiliki makna bahwa kualitas pelayanan secara statistik berpengaruh terhadap kepuasan pelanggan, (3) kepuasan pelanggan berpengaruh positif dan signifikan terhadap loyalitas pelanggan, yang didasarkan pada hasil perhitungan nilai signifikansi sebesar $0,010<0,05$, yang memiliki makna bahwa kepuasan pelnggan secara statistik berpengaruh terhadap loyalitas pelanggan, (4) kepuasan pelanggan memiliki peran mediasi secara parsial pada pengaruh positif dan signifikan dari kualitas pelayanan terhadap loyalitas pelanggan, yang didasarkan pada hasil perhitungan nilai signifikansi sebesar 0,010<0,05, yang memiliki makna bahwa kepuasan pelanggan mampu memediasi antara kualitas pelayanan dan loyalitas pelanggan.

Implikasi manajerial yang dapat diberikan berdasarkan hasil penelitian ini adalah sebagai berikut. (1) Pihak manajemen Prime Plaza Suites Sanur - Bali dapat memberikan pelatihan dan orientasi seputar pelayanan jasa kepada karyawan sehingga dapat menerapkan pelayanan yang optimal kepada tamu yang menginap serta dapat memberikan pelatihan atau sosialisasi tentang keseteraan dalam dunia kerja, baik itu 
kesetaraan agama, gender, ras maupun status ekonomi dan sosial. (2) Pihak manajemen Prime Plaza Suites Sanur - Bali perlu adanya evaluasi dan melakukan strategi untuk meningkatkan tamu yang loyal seperti memberikan pelayanan tambahan diluar penagihan biaya, seperti halnya memberikan ucapan ulang tahun melalui email kepada setiap database tamu yang dimiliki oleh perusahaan. (3) Pihak manajemen di Prime Plaza Suites Sanur - Bali dapat memetakan wilayah dan lokasi yang jelas mengenai lokasi hotel ini, sehingga ketika tamu mencari informasi seputar lokasi dapat dengan mudah memperoleh akses informasi tersebut.

Untuk penelitian mendatang agar menggunakan variabel lain yang dapat mendukung komposisi metode yang lebih baik seperti emotional bonding, kepercayaan pelanggan serta perceived value dan sampel dengan jumlah yang lebih besar apabila meneliti mengenai peran mediasi dari rangkaian kesatuan kualitas dan kepuasan guna mendapatkan hasil penelitian yang lebih optimal.

\section{DAFTAR PUSTAKA}

Abd-Elaziz, M. E., Aziz, W. M., Khalifa, G. S., \& Abdel-Aleem, M. (2015). Determinants of Electronic word of mouth (EWOM) influence on hotel customers' purchasing decision. International Journal of Heritage, Tourism, and Hospitality, 9(2/2), 194223.

Ananda, S dan Devesh, S. (2016). Service Quality and Customer Satisfaction: A Studi Case in The Perception Of Retail Banking Customer In Oman. 17th International Scientific Conference on Economic and Social Development, 20- 21 October 2016, Warsaw, Poland. Hal 333-344.

Badarudin, M. Ramzi. (2010). Journal Customer Loyalty and the Impacts of Service Quality:The Case of Five Star Hotels in Jordan. International Journal of Human and Social Sciences in Jordan. 5 (3).

Baron R. M. dan David A. Kenny. (1986). "The Moderator-Mediator Variable Distinction in Social Psychological Research: Conceptual, Strategic, and Statistical Considerations". Journal of Personality and Social Psychology, Vol. 51, No. 6, pg. 1173 - 1182.

Galib Mohammed. 2013. Journal The Impact of Service Quality on Customers Loyalty A Study on Five Stars Hotel's Customer in Riyadh. European Journal of Business and Management. 5 (31)

Juni, Priansah, Donni. (2017). Perilaku Konsumen Dalam Persaingan Bisnis Kontemporer. Penerbit Alfabeta, Bandung.

Kandampully, J., \& Suhartanto, D. (2000). Customer loyalty in the hotel industry: the role of customer satisfaction and image. International Journal of Contemporary Hospitality Management, 12(6), 346-351.

Kandampully, J., Juwaheer, T. D., \& Hu, H.-H. (2011a.) The influence of a hotel firm's quality of service and image and its effect on tourism customer loyalty. International Journal of Hospitality \& Tourism Administration, 12(1), 21-42.

Kotler dan Keller. 2012. Marketing Management. Fourteenth Edition. England: Printice Hall.

Mamang, Sangadji Etta dan Sopiah. 2013. Perilaku Pelanggan Pendekatan Praktis. Penerbit Andi. Yogyakarta.

Mohamad, H. A. D., Ab Yazid, M. S., Khatibi, A., \& Azam, S. F. (2017). Service quality, customer satisfaction and customer loyalty of the hotel industry in United Arab Emirates (UAE): A measurement model. European Journal of Management and Marketing Studies.

Parasuraman, A,.Valerie A. Zeithaml, and Leonard L. Berry,. (1988). SERVQUAL: A Multiple Item Scalefor measuring Consumer Perception of Service Quality. Journal of Marketing, vol 64, p 12-40 
Skogland, I., \& Siguaw, J. A. (2004). Are your satisfied customers loyal?. Cornell hotel and restaurant administration quarterly, 45(3), 221-234.

Sudigdo, A., Khalifa, G.S.A., Abuelhassan, A.E., (2019). Driving Islamic Attributes, Destination Security Guarantee \& Destination Image to Predict Tourists' Decision to Visit Jakarta. Int. J. Recent Trends Bus. Tour. 3, 59-65. Tariq, M., Abbas.

Trung, N. V. H., \& Khalifa, G. S. A. (2019). Impact of Destination Image Factors on Revisit Intentions of Hotel's International Tourists in Ba Ria-Vung Tau (BR-VT) The Mediating Role of Positive Word-of-Mouth. International Journal on Recent Trends in Business and Tourism, 3(2), 98-107. 